\title{
The Examination of Budgeting Reality at University Based on Public Services Agency
}

\author{
Nilawaty Yusuf ${ }^{1} \quad$ Niswatin $^{2} \quad$ Nadira S. Sidik $^{3} \quad$ ST. Hartina Putri $\mathrm{N}^{4}$ \\ Accounting Department, Economics Faculty, Gorontalo State University
}

\begin{abstract}
The principles of Good University Governance (GUG) need to be developed in all academic activities and university management. The most important part of university management to affect university performance is the budgeting. This study aims are 1) to review the implementation of Gorontalo State University budgeting and 2) to identify the conflicts occurred in preparation of Gorontalo State University budget. This research is conducted by descriptive qualitative method. The data is collected by (1) in-depth interviews with experts to explore the budgeting process at Gorontalo State University and (2) observation and documentation of budgeting at university level. This research departs from knowledge and awareness related to budgeting, especially in institutions based on Public Service Agency. The results of study indicate that budgeting mechanism generally starts from the planning stage, namely Strategic Plan, then Business Plan and Budget development refers to Strategic Plan. The involved parties are planning department, Supervisory Board, Internal Supervisory Unit and leadership in each work unit. The reality show that the budget preparation conflict is each unit has an interest to meet their respective needs.
\end{abstract}

Keywords: Good University Governance, Budgeting, Strategic Plan, Business Plans and Budgets

DOI: $10.7176 /$ RJFA/12-22-10

Publication date: November 30th 2021

\section{INTRODUCTION}

Accounting is an activity to provide financial information to make economic decisions (Sulistiawan et al., 2011). Sulisnayanti et al. (2017) also explained that accounting is the process of identifying, collecting and storing data along with developing, measuring and communicating the information. The financial information can facilitate to determine the policies application to achieve the objectives effectively and efficiently. Accounting is also a tool to provide an overview of economic conditions as the company's indicator in policies making. Niswonger et al. (2000) stated that accounting can be defined as an information system to produce reports for interested parties regarding economic activities and company conditions. The budgeting is realization of accounting as a tool in decisions making.

The budget is the output for estimation in the future. The budgeting is an activity process to produce the budget as the output and activity processes related to implementation of budget function, namely the function of work guidelines, work coordinating tools and work monitoring tools (Lubis, 2017). The budget is very important to support the performance of an institution or agency related to process of activities in order to do the function of budget as a work guide. The budget is also defined as a tool in controlling, communicating, evaluating performance, coordinating and as motivation (Libby \& Lindsay, 2010). The budget is also interpreted as a financial reflection determined by government or related parties to make economic and social policies (Siegel, 1989). Santoso (2018) stated that budgeting process was a budget allocation mechanism within an agency to support the main tasks and functions of organization in one period, usually one year. The general stages of budgeting are planning, ratification, implementation and reporting (Yesyan et al., 2021).

Conflicts in university's budgeting process as one government education institutions cannot be avoided. It relates with interests of units and departments to get education financing. Conflict behavior in budgeting process is inevitable related to political influence of faculty in budgeting when they demand to get education funding. Adversely, the administrators tend to use budgetary rules rigidly as an effort to defend the public interest (Santosa, 2018). Sopanah et al. (2017) stated that dominance of legislative and executive institutions creates opportunity to corrupt the budget. Santosa (2018) also stated that tendency to use political influence and power in decision making relate with discretion institution due to excess budget.

The financial management system in Indonesia government has vulnerable problems both in context of budgeting and aspects of morality. Indonesia country is influenced by orientalist principles, rich in local wisdom values, but is still wallowing in problems that contrary to values. The local wisdom becomes a shield from actions to seek power, income, reputation, publicity, prestige, and patronage (Tenrigau et al., 2017).

Niswatin and Yusuf (2015) examined the budgeting at Gorontalo State University (UNG). The data was analyzed by Analytical Hierarchy Process (AHP). The results showed that study program accreditation is the main program priority in the preparation of Business Plans and Budgets. This research results have been used as the basis for policy-making for study program leaders to offer work programs to faculty level. Yusuf and Niswatin (2019) found no conflict in budgeting process at accounting department level because the Department Head had 
the power in preparation of Business Plans and Budgets, interaction of his strengths create a togetherness-based Business Plans and Budgets. This study results contradict with the explanation of Tenrigau et al. (2017) and Santoso (2018) that budgeting in public sector is vulnerable to conflicts of interest.

This research urgency is the Gorontalo State University as a Public Service Agency institution whose budgeting process is centered on each work unit. The problem formulation of this study are (1) how is the implementation of budget preparation of Gorontalo State University? and (2) what conflicts in budget preparation at Gorontalo State University. The research aims are 1) reviewing the budgeting implementation at Gorontalo State University and 2) identifying the conflicts in budget preparation at Gorontalo State University.

This research has contribution to review the budgeting process at Gorontalo State University related to mechanism, parties involved and the conflicts. It should be used as an operational reference by universities in realizing Good University Governance (GUG).

\section{LITERATURE REVIEW}

\section{College Budgeting}

The budget is the output in form of future estimation. The budgeting is the process of activities to produce the budget as a result of work and process of activities related to implementation of budget function related to work guidelines, work coordinating tools and work monitoring tools (Lubis, 2017). The budget is also defined as a tool in controlling, communicating, evaluating performance, coordinating and as motivation (Libby \& Lindsay, 2010). Santoso (2018) defined budget process as an allocation mechanism within an agency to support the main tasks and functions of organization in one period, usually one year.

The success of budgeting process in universities is determined by leadership's ability to manage conflicts during the budgeting process (Santoso, 2018). Higher education leaders should make neutral internal policies. Budgeting process in an institution always refers to Strategic Plan of university. The Strategic Plan contains statements of vision, mission, programs, strategic plans, operational/activity plans and budget work plans. These are then realized in annual activities called annual work plans.

\section{Colleges with Public Service Agency Status}

Government agencies can be seen from mechanic view as part of bureaucracy or an organic view as a dynamically developing organization. The organic view point of view explained that government agencies can be perceived as government agents to serve the community (public service agency). It is a kind of autonomous body that remains part of government and implements sound business principles, but does not have profit orientation.

The issuance of Law No. 1 of 2004 on the State Treasury introduced the Public Service Agency of Financial Service Pattern for working units that provide services to public. The provisions of Financial Service for Public Service Agency are regulated in articles 68 and 69 and translated into Government Regulation Number 23 of 2005 on Financial Service for Public Service Agency. This opens a new corridor for implementation of performance base in government circles. The government agencies have task and function to provide services to public through flexible financial management patterns by highlighting productivity, efficiency, and effectiveness. This Public Service Agency should become a prominent concrete example of implementation of financial management based on performance.

The opportunity to become a Public Service Agency work unit is open to government work units with operational tasks of public services (such as health services, education, area management, licensing and fund management), to distinguish them from the government's function as regulators and policy makers. This practice has been widespread in many countries is an effort of agencification activity by pure bureaucracy institution, but managed by business like agency to deliver more efficient and effective service to community.

Public Service Agency in field of education provides education to public at various levels, including high school, academy, institute, university, and other education. There are three main categories of Public Service Agency in education. First Higher Education under the Ministry of Education and Culture, it consists of Universities and Polytechnics providing higher education for wider community. Second, Religious Higher Education under the Ministry of Religion, it consists of Universities and Religious Institutes providing higher education for wider community. Third, Service Education under K/L, it consist of Education and Training Centers, Polytechnics, Academy and Colleges providing education special skills which all/part of graduates are intended to meet the internal needs of Ministries/Agencies.

\section{Budgeting Conflict}

The relationship between humans is certainly inseparable from conflict. The basic point of view of conflict is illustrated through Turner's perspective that such conflict is designed to resolve dualism, it is a way to achieve a kind of unity, even if it is through the annihilation of one of conflicting parties. Wes Sharrock in Pip Jones (2009) also explains that conflict view is built on assumption that every society can provide an extraordinary good life for some people, but this is usually only possible because most people are oppressed. 
Interests differences in society are as important as with agreement on rules and values, and most people are organized in such a way that community not only provides greater benefits for some citizens, it means inconvenience for some other citizens who do not get the convenience (Mas'udi, 2015). Santosa (2018) stated that budgeting process requires great time and attention, struggle for influence and interests in budgeting process often arises in organizations. This happens because each unit and section has activities that must be fought for in an effort to maintain sustainability of program and existence of the institution.

\section{Good University Governance}

Pusser and Ordorika (2001) stated that University Governance was a governance concept developed in universities in response to larger and more complex universities, more important role of universities as social institutions and more government funding that requires supervision. University Governance in Indonesia is still oriented to faculty model. Government Regulation of Republic of Indonesia No. 66 of 2010 on Amendments to Government Regulation No. 17 of 2010 Article 58F paragraph 1 on Management and Implementation of Education explained that higher education management structure organized by government includes (1) the rector, chairman or director running higher education autonomy for and on behalf of minister, (2) the senate of universities, institutions, high schools, academies or polytechnics gives consideration and supervises the chancellor, chairman or director, (3) the supervisory unit supervises the implementation of higher education autonomy in non-academic field for and above the name of rector, chairman or director, (4) the deliberative board gives consideration to autonomy of higher education in non-academic fields and other functions according to statutes to rector, chairman or director. Furthermore, Sayidah (2017) stated that University Governance should follow the principles of autonomy, quality assurance, transparency and accountability.

Good University Governance (GUG) is seen as the implementation of basic principles of "good governance" concept in governance system and process at higher education institutions, through various adjustments based on values that must be upheld in administration of higher education and general education. The principles of good governance are still relevant to be applied in good university governance. The higher education institution must comply with principles of participation, consensus orientation, accountability, transparency, responsiveness, effectiveness and efficiency, equity, inclusiveness and law enforcement / supremacy (Slamet, 2014).

\section{RESEARCH METHODS}

This study used qualitative research methods. Qualitative research is developed in social sciences to understand social and cultural phenomena (Myers, 2009) and produces descriptive data in form of written or spoken words from people and observed behavior (Moleong, 2019). This research was conducted at Gorontalo State University for 5 months from April to August 2021. The primary data was collected from interviews with key informants, supporting informants and Focus Group Discussions (FGD) with experts. Secondary data is collected from University Strategic Plan and University Business Plan and Budget.

The data collection techniques were complementary, consisting of: interviews, observation, documentation and Focus Group Discussion (FGD). The data validity was supported by diligence in interviews, and adequacy of available documents. The data analysis technique was done by qualitative analysis techniques with stages of data reduction, data presentation and conclusions.

\section{RESULTS AND DISCUSSION}

\section{Initial Description of the Budgeting at Gorontalo State University}

Gorontalo State University (UNG) is developed from the expansion mandate of Gorontalo State IKIP. The change of Gorontalo State IKIP to UNG was stipulated by Presidential Decree Number 54 of 2004, dated June 23. UNG's birthday was determined to be the same as the birth of branch of UNSULUTTENG FKIP in Gorontalo, namely September 1, 1963 as stated in Decree of Minister of PTIP Number 67 of 1963, dated July 11.

UNG as a state university has made management improvements through a change in management paradigm based on Public Service Agency on April 21, 2009 based on Decree of Minister of Finance No. 131/KMK.05/2009 (Gorontalo State University - PPK BLU Website - ViewBlu) .

Ministry of Education and Culture stipulates the Regulation of Minister of Education and Culture of Republic of Indonesia Number 20 of 2013 on UNG Accounting System. In welcoming the Minister of Finance Regulation Number 220/PMK.05/2016 on the Financial Accounting and Reporting System of Public Service Agencies, UNG entrusts Syncore Consulting as a renewal partner in standardized financial management and reporting ( https://blud.co.id/wp/ 2018/22/universitas-negeri-gorontalo ).

The preparation of budget is very important to improve university performance, especially to support the financing in each unit. The budget is also related with Good Corporate Governance (GCG), in realm of universities is known as Good University Governance (GUG). There are four principles, namely accountability, transparency, credibility and responsibility. YK as the Vice Chancellor II of UNG clearly stated:

"The theoretical concept of Good University Governance has four principles, namely accountability, 
transparency, credibility and responsibility."

Related to Good University Governance, AA as the Postgraduate Director of UNG said that:

"Good government has four elements, namely responsibility, accountability, transparency and fairness."

The sample for budgeting is Faculty of Economics which has students than other faculties. The budget determination is slightly different. However, university does not just let this happen, but finds a solution to mediate the problems of other faculties. In a sense, faculties with few students can get sufficient budget to do the same activities. They are motivated to help each other. As stated by YK:

"The budget determination at Faculty of Economics always considers the number of students that different from other faculties. Even though they differ in budgeting, other faculties can still do the same activities. It is mo baku bantu (cross subsidies)."

AA also added that budgeting is student-based, the measurement is students. Students are the main element in university activities. However, efforts are still being made to evenly distribute in each faculty.

"Budgeting is student-based, the size is students. However, the distribution must even because the number of students is different in each faculty, which is called cross subsidies."

The cross subsidy system in budgeting is a solution to overcome the inability and limitations to meet the needs of each work unit. It needs to set the priority scales. The proposal from each work unit is not based on a proportional principle in ability to contribute. Cross subsidies are a solution to overcome these problems. RM as Deputy Dean III of UNG Faculty of Economics stated:

"Inability or limitations sometimes do not meet the needs of proposals from each work unit. It needs to determine based on priority scales. This is also a question of ego of each work unit, namely where the proposal process is not based on a proportional principle. As a solution to these problems, UNG sees how operations can run in all units, namely cross subsidies."

\section{Funding Sources}

There are three groups of funding sources, namely APBN, PNBP and PKLN. The APBN is more focused on routine financing, usually related to operations such as employee salaries, electricity, cleaning, security and others. While PNBP or Non-Tax State Income mostly comes from student tuition used to support routine operations. The PKLN is a foreign loan where Indonesia cooperates with Saudi Arabia, Jeddah. The loan is termed as grant, where the allocation of funds must be in accordance with basis of proposal. RM added:

" The funding sources come from three groups, namely APBN, PNBP and PKLN. The state budget mostly finances the routines operation. PNBP mostly comes from student tuition used to support routine operations. The PKLN is a loan, for example, UNG gets a loan from abroad where Indonesia cooperates with Saudi Arabia, Jeddah. The loan is termed a grant and must be allocated in according with proposal."

\section{Budgeting Mechanism}

\section{Making Strategic Plans}

The budgeting mechanisms cannot be separated from a plan. Bottom up based planning process facilitates the work unit proposes their important need to budget. The planning stage contains an agreement on amount needed by each work unit through socialization done by Planning Section. The results of agreement become the basis to submit a budget proposal to ministry. RM clearly stated:

"We start the budgeting from the planning side. The UNG planning agency conducts a study with ministry because our budget is part of ministry. The planning head makes conduct a socialization to re-sharpen the budget plan that will be prepared by involving all work units. It is called planning process, the bottom-up system usually facilitates the work unit proposes what is important."

Above statement is also supported by IY as Deputy Dean II of UNG Faculty of Economics that: "Faculty only makes proposal, review and determination of budget is determined at university level."

Preparation of Strategic Plan is started by collecting information from each faculty regarding the shape and direction of policy. The programs that have been proposed will be adjusted to Strategic Plan of Ministry of Education and Culture. Furthermore, for preparation of Business Plans and Budgets, a workshop will be held at end of each year to determine what programs will be implemented. A team was formed to verify the target and amount of budget and person in charge. IH as Vice Chancellor IV UNG stated below:

"The first strategic planning process is to collect information from each faculty based on their policy direction. We filter and adjust the programs according to strategic plan of Ministry of Education and Culture. We held a workshop at end of this RAB at end 
of every year to determine what programs will be implemented in current year. After that, we will create a team that will verify what target is, how much the budget and people responsible."

Above statement is also explained by RM:

"As the part of Ministry, the activities program for five years in strategic plan refers to strategic plan from the ministry."

The parties involved in preparation of Business Plans and Budgets were technically taken over by planning department. The strategic plan itself has special team consist of Vice Chancellor II and WR IV, faculty leaders and related parties. It also measures or reviews the achievement level of Strategic Plan for each work unit. IH said that: "Planning department technically take over the Business Plans and Budgets. But if the size of strategic plan is in our hands, how to make it, including we have measured/reviewed the achievement level of Strategic Plan for each UNG work unit."

He added:

"We want to involve more but it is not efficient. We also involve a few busy people, so I think it's a small team but will be backed up by a big team that will review it later."

IH explains that the team to formulate the Strategic Plan only involved a few people. The more people can lead to inefficient formulation. This small team is backed up by a large team in charge of reviewing. The involvement of external parties has not yet been done. IH added:

"We don't have a consultant Strategic Plan, but the important point is that I don't know

how to involve external parties."

\section{Preparation of Business Plan and Budget}

The Business Plan and Budget is prepared before the following year. It should be consistent with Strategic Plan that contains programs implementation in coming year. It contains the needs and capabilities of revenue budget, the financing covered in Business Plans and Budgets. RM explained:

"Business Plans and Budgets for 2022 have at least been compiled since 2021. This refers to strategic plan that has been prepared for five years. The strategic plan basically contains the program activities will be done for one year. It contains the needs and capabilities of revenue budget and financing covered in Business Plans and Budgets."

This statement is supported by Santoso (2018) that budgeting is a budget allocation mechanism within an agency to support the main tasks and functions of organization in one period, usually for one year. Wheelen $\&$ Hunger (2012) stated that budget contains activities that will be done during a certain period of time as a reference for organizational activities and shows the company's operational goals.

Each work unit proposes different proposal in preparing the budget. a Rector's Decree was issued as a forum for budget distribution to accommodate this, hopes and desires of each work unit. The decree will be issued prior to finalization and review with ministry and discussions with work units to find need for each work unit. RM stated:

"Yes, there is a Rector's Decree before finalization. The planning team departs to conduct a study with ministry. There are stages on how to meet first from the work unit with planning team to formulate how many needs the work unit wants which will be adjusted to level of budget capability of UNG. The Rector's Decree has gone through the budget distribution process, and accommodated the expectations, although it still needs improvement. Some work units also makes a little pressure with various considerations that cake they get is still too far from what they want."

Supervisory Board has a duty to supervise the financial management in each work unit. Supervision is done by Supervisory Board directly to each work unit. Public Service Agency handed over the financial management authority directly to work unit. The performance appraisal of Supervisory Board is highly dependent on performance of work unit. Work unit with good performance will makes Supervisory Board produce the same performance. It was clearly stated by RM as Secretary of Supervisory Board:

"The supervisory agency has a fairly severe consequence from the perspective of central government when an ordinary work unit leads to Public Service Agency. The consequence is financial matters was taken from center to work unit when one it became a public service agency. The success or failure of a work unit has a big effect on role supervisory agency because the main function is to oversee. Bad work unit will make the supervisory agency bad."

Internal supervisory unit is also involved in preparation of budget. Internal supervisory unit serves as a consultant who provides advice and input regarding financial reports before submitted to center. Internal supervisory unit becomes a consultant. As explained by MR as the head of UNG Internal Supervisory Unit:

"We become consultant for this budgeting. For example, there are several faculties in 
preparation of Business Plans and Budgets, budgeting and pricing. We only become consultant. Rector always involved Internal supervisory unit in each meeting on finances to provide input. Internal supervisory unit is also not a policy maker, we only recommend it, and we convey it to leadership as the basis for decision making".

\section{Conflicts in Budgeting}

There are conflicts in budgeting. The problem is delays in ratification at State Treasury Service Office in Gorontalo region because they have to adjust the Main Performance Indicators. The next process can not be done if the planning has not been completed. This is expressed by YK:

"We are late to ratify the KPPN. We have to adjust the Main Performance Indicators, we cannot make a budget it if the planning section has not been completed."

The problem in preparing the budget was also expressed by RM:

"Sometimes it also involves ego problem of each work unit, namely where the proposal process is not based on a proportional principle. This means that in simple language, the ability to contribute to institution is very small, but it demands a very extraordinary. On other hand, sometimes the conditions are reversed, sometimes there are work units with high level of ability but are encouraged to propose the desired needs."

The statement above reveals problems related to egoism of budget distribution in each work unit. The proposal is disproportionate in terms of small contributions and large demand. Work units with large contribution also demanded the desired needs. They prepare Business Plans and Budgets with desire to get a budget in accordance with needs of work program, especially for units with most student resources. However, budget constraints force some unit to be subsidized in order to continue their work program.

The budget usage and accountability also create conflicts. From Internal supervisory unit point of view, conflicts occur when Decree on determination of Remuneration is not updated, only refers to old policy. Related to accountability, negligence administration is shown when receipts that have not been signed. MR explains:

"There is no problem for current budget, but in auditing process we found some provisions that have been too long, for example Decision Letter for determination of remuneration, the remuneration refers to decree of 2014, while now it is 2021 . We found there are several responsibilities, especially negligence in administration, for example, receipts that have not been signed."

These conflicts are consistent with explanation of Tenrigau et al. (2017) and Santoso (2018) that budgeting in public sector was vulnerable to interest conflicts.

\section{CONCLUSION}

Based on research results and discussions of budget preparation at Gorontalo State University, it can be concluded that preparation of UNG budget is based on Public Service Agency, which focuses on work units. The budgeting is based on students to support their interests and needs. The initial stage in preparing the budget is planning, in this case making the Strategic Plan. After the Strategic Plan, a Business Plans and Budgets is created based on Strategic Plan. It involves Planning Section, Supervisory Board, Internal Supervisory Unit and leadership in each work unit.

The budgeting process requires a common understanding of arguments and perceptions. Gorontalo State University is also not free from conflicts. It is related to ego in each work unit to get what they propose to leadership. Each unit prepares Business Plans and Budgets based on needs of work program, especially for unit that has the most student resources. However, there are units that need to be subsidized in order to continue their work program. Each unit has an interest to meet their respective needs. The budgeting examination at Gorontalo State University provides an overview on the actual budgeting process. It provides space to contribute ideas in form of solutions to solve the problem.

\section{REFERENCES}

https://blud.co.id/wp/2018/22/universitas-negeri-gorontalo, Universitas Negeri Gorontalo: Terus Memantapkan Diri dalam Pola Pengelolaan BLU berbasis Good University Governance. Diakses tanggal 16 Maret 2021).

Direktorat Jenderal Perbendaharaan Kementerian Keuangan Republik Indonesia. (2013). Buku Manual Pengelolaan Satker BLU Bidang Layanan Pendidikan.

Libby, T. and Lindsay, M. (2010) 'Beyond budgeting or budgeting reconsidered? A survey of North-American budgeting practice', Management Accounting Research, vol. 21, no.1.

Jonathan H Turner, The Structure of Sociological Theory. (1975). Illiois: The Dorsey Pers. hlm. 84.

Lubis, Arfan Ikhsan 2017. Akuntansi Keperilakuan. Akuntansi Multiparadigma. Salemba Empat. Jakarta

Mas'udi. (2015). Akar-akar Teori Konflik: Dialektika Konflik; Core Perubahan Sosial dalam Pandangan Karl 
Marx. Jurnal Fikrah, 3(1), 177-200.

Moleong, Lexy. (2019). Metodologi Penelitian Kualitatif. Remaja Rosdakarya. Bandung

Myers, Michael D. (2009). Qualitative Research in Business \& Management. SAGE Publication Ltd.

Niswatin dan Nilawaty Yusuf. (2015). Prioritas Program Kerja Sebagai Dasar Penyusunan Rencana Bisnis Anggaran (RBA) Unit Kerja Program Studi S1 Akunatnsi. Jurnal Ilmiah Akuntansi dan Humanika. Vo 4. No 2. Juni. ISSN 2089-3310. Penerbit Jurusan S1 Akuntansi Fakultas Ekonomi Dan Bisnis Unidiksha. Bali

Niswonger, C. R., Warren, C. S., Reeve, J. M., \& Fess, P. E. (2000). Prinsip-Prinsip Akuntansi (Edisi Ke-19; T. Sihombing, ed.). Jakarta: Erlangga.

Pip Jones, Pengantar Teori-Teori Sosial dari Teori Fungsionalisme hingga Post-Modernisme, terj., Achmad Fedyani Saifuddin. (2009). Jakarta: Yayasan Obor Indonesia, hlm. 15.

Pusser, B dan I,Ordorika. (2001). Bringing Political Theory To University Governance: A Comparative Analysis of Governing Boards At The Universidad Nacional Autonoma de Mexico and the University of Calofornia. In J.C. Smart (ed). Higher Education : Handbook of Theory and Research, Volume XVI. Agathon Press. New York.

Sayidah, Nur. (2017). Model University Governance dalam Dimensi Ketauhidan. Sebuah Rekonstruksi Berbasis Riset Kritis. Zifatama Jawara. Surabaya.

Santosa, Achadi B. (2018). Penganggaran Pendidikan Tinggi Dalam Prespektif Allan G. Schick. Prosiding Konferensi Nasional Ke- 7. Asosiasi Program Pascasarjana Perguruan Tinggi Muhammadiyah 'Aisyiyah (APPPTMA). ISBN 978-602-50710-5-8. Jakarta 23 - 25 Maret.

Siegel, G. Marconi. (1989). Behavioral Accounting. South Western Publishing Co. Second Edition

Sopanah, A. N. A., Safriliana, R., \& Harmadji, D. W. I. E. (2017). Public Participation on Local Budgeting Base on Public Participation in Budgeting. 11, 10-18.

Slamet. (2014). Implementasi Konsep Badan Layanan Umum pada Perguruan Tinggi Agama Negeri dalam Mewujudkan Good University Governance. Laporan Hasil Penelitian Individu. Fakultas Ekonomi. Universitas Islam Negeri Maulana Malik Ibrahim Malang

Sulisnayanti, N. L. G., Wahyuni, M. A., \& Julianto, I. P. (2017). Penerapan Sistem Informasi Akuntansi Persediaan Berbasis Komputer Terhadap Perencanaan Dan Pengendalian PERSEDIAAN BARANG DAGANGAN (Studi Kasus Pada UD. Pindang Panjul Segara, Banjar Yeh Gangga, Desa Sudimara, Kecamatan/Kabupaten Tabanan ). E-Journal S1 Ak Universitas Pendidikan Ganesha, $8(2)$. https://ejournal.undiksha.ac.id/index.php/S1ak/article/view/13488

Sulistiawan, Dedhy., Yeni Januarsi dan Liza Alvia. (2011). Creative Accounting: Mengungkap Manajemen Laba dan Skandal Akuntansi. Penerbit Salemba Empat. Jakarta.

Tenrigau, Andi Mattingaragau, Iwan Triyuwono, Darwis Said, dan Ratna Ayu Damayanti. (2017). Menemukenali Konsep Penganggaran Siri' Na Pesse: Studi Kasus Berbasis Kearifan Lokal di Kabupaten Luwu Timur. Disertasi. Universitas Hasanuddin. Makassar.

Wheelen, T.L., and Hunger, J.D., 2012, Strategic Management and Business Policy Toward Global Sustainability, University of Virginia, Pearson

Yesyan, A., Mangantar, M., \& Tulung, J. E. (2021). The Effect of Performance-Based Regional Expenditure Revenue Budget Based Regional Expenditure Revenue Budget and Good Government Governance o $n$ Performance Accountability of Local Government Institutions f Local Government Institutions in Tambrauw Regenc. 